\title{
Ensuring Regional Security in the Context of Economic Aspects of Sustainable Development
}

\author{
Elena Kazantseva ${ }^{1}$, and Galina Chistyakova ${ }^{1}$ \\ ${ }^{1}$ Plekhanov Russian University of Economics, Kemerovo Institute (branch), 650992 Kuznetsky Av. \\ 39, Kemerovo, Russia
}

\begin{abstract}
Sustainable development is one of the priorities of the world development. It combines the need for simultaneous harmonious development of society in ecological, economic and social areas. The paper is devoted to the economic security of regions as an integral component of their sustainable development. Basic documents in the field of ensuring security of the Russian Federation in the context of regional economic security are considered. The authors analyze the indicators of national economic security that can be used at the regional level including those applied for assessing economic security of resource-producing regions. Suggestions on improvement of methodical approaches to evaluating and ensuring regional economic security are made.
\end{abstract}

\section{Introduction}

Sustainable development is of particular importance for resource-producing regions [1], including the Kemerovo region. They face the problems of high level of environmental pollution, low rates of economic growth, insufficient innovative potential, etc. To solve them, integrated efforts of both federal, regional and local authorities, business and civil society are required [2].

The Resolution adopted by the General Assembly on 25 September, 2015, No 70/1 "Transforming our world: the 2030 Agenda for Sustainable Development" recognizes the importance of regional and subregional factors, regional economic integration and interaction in the field of sustainable development. Regional and subregional mechanisms can contribute to effective implementation of sustainable development strategies into particular actions at the national level.

The security of regional economic systems is the necessary condition for sustainable development of regional economy. Besides, regional economic security is one of the most important components of the national economic security. At present, the level of economic security of different Russian regions varies significantly, which has an adverse effect on the economic security of the country. This challenge is a matter of concern for federal and regional authorities as well as an area for scientific researches.

\footnotetext{
* Corresponding author: 9059655017@mail.ru
} 


\section{Materials and methods}

To assess the level of regional economic security, the materials of the Federal State Statistics Service of the Russian Federation, regulatory legal acts, the results of the researches carried out by the rating agency "RIA Rating", and the authors' calculations were used. The study is based on the methodology of system analysis.

When forming economic security at the regional level, the priorities, areas and ways of development identified at the level of the Russian Federation in terms of ensuring national security, socio-economic development of the country for the long run, and development priorities at the level of federal districts are taken as a basis. At the same time, it should be taken into account that regional economic security is specified with the need for regions to develop within the framework established by the federal centre. It largely depends on the current system of interbudgetary relations, the level of social and economic development. This level is closely connected with specialization of regions, the presence of single-industry towns and export potential. To increase the level of economic security of Russian regions, it is necessary to search for some new ways of development considering current and potential competitive advantages.

The documents defining strategic priorities for regional development, in particular, the Concept of Long-term Socio-economic Development of the Russian Federation for the period up to 2020 (the Decree of the Government of the Russian Federation of November 17, 2008, № 1662-r (as amended on 10.02.2017) emphasize that ensuring a balanced socio-economic development of regions requires stimulation of economic development by means of creating new centres of economic growth in the regions. The future of the regions of the Russian Federation is associated with different vectors of development (Table 1).

Table 1. Vectors of development of Russian regions.

\begin{tabular}{|c|c|c|}
\hline Region & Vector of development \\
\hline Central Region & $\begin{array}{c}\text { Advancing high rates of economic growth of the Moscow urban } \\
\text { agglomeration to nearby territories, modernizing machine building, } \\
\text { metallurgy, chemistry and petrochemistry, aviation and light industry. }\end{array}$ \\
\hline $\begin{array}{c}\text { Central Black } \\
\text { Earth Region }\end{array}$ & $\begin{array}{c}\text { Applying innovative technologies for agriculture, modernizing } \\
\text { agricultural processing, mining and metallurgical industries. }\end{array}$ \\
\hline $\begin{array}{c}\text { North-West } \\
\text { Region }\end{array}$ & $\begin{array}{c}\text { Using the potential of the St. Petersburg urban agglomeration, access to } \\
\text { marine communications. Developing transport and business services } \\
\text { sectors, military-industrial complex, shipbuilding, instrument engineering, } \\
\text { electrical engineering, metallurgy, chemistry and biopharmaceutical } \\
\text { industries. Using new technologies in the extractive sector, metallurgy, } \\
\text { timber industry, mining and processing of aquatic biological resources. }\end{array}$ \\
\hline South of Russia & $\begin{array}{c}\text { Using favourable natural and climatic conditions for developing } \\
\text { agriculture, tourism, transit transport services. }\end{array}$ \\
\hline Volga Federal \\
District & $\begin{array}{c}\text { Modernizing aerospace industry, chemical and petrochemical industries, } \\
\text { developing modern services sector. }\end{array}$ \\
\hline Ural Federal \\
District & $\begin{array}{c}\text { Developing extractive industries, deep processing of raw materials, } \\
\text { scientific and innovation centres, sectors of business, innovation, } \\
\text { educational and other services, modernizing heavy and transport } \\
\text { engineering industries. }\end{array}$ \\
\hline Siberia & $\begin{array}{c}\text { Using natural resources, their deeper processing in existing centres of } \\
\text { industrial growth, creating new industrial and scientific centres. }\end{array}$ \\
\hline Far East & $\begin{array}{c}\text { Developing natural resources, using an advantageous seaside } \\
\text { geographical position and proximity to the markets of Asia-Pacific } \\
\text { countries. }\end{array}$ \\
\hline
\end{tabular}


The vectors for the development listed in Table 1 were identified in 2008, however, nowadays many challenges of regional development are still relevant. In the Strategy of Economic Security of the Russian Federation until 2030 (Presidential Decree of May 13, 2017, No. 208) the main challenges and threats to economic security are recognised as follow: uneven spatial development of the country, increasing the differentiation of regions and municipalities in terms of the level and pace of socio-economic development. Based on the data on "The Gross Regional Product for the Subjects of the Russian Federation in 19982015 " of the Federal State Statistics Service, the share of the ten largest subjects in terms of Gross Regional Product (GRP) is determined. In 2000 this index accounted 52.4 percent, in 2010 it reached 55.2 percent, and in 2015 it was up to 54.3 percent. The top ten GRPs traditionally include Moscow, St. Petersburg, the Tyumen Region, the Krasnoyarsk Territory, the Sverdlovsk Region, the Krasnodar Territory, the Samara Region, the Republic of Bashkortostan, the Republic of Tatarstan (Table 2).

Table 2. The ten largest subjects of the Russian Federation in terms of GRP in 2010 and 2015 (in billions of rubles and as a percentage of total GRP by regions).

\begin{tabular}{|c|c|c|c|c|c|}
\hline \multicolumn{3}{|l|}{2000} & \multicolumn{3}{|l|}{2015} \\
\hline Region & GRP & $\%$ & Region & GRP & $\%$ \\
\hline Moscow & 1159 & 20.1 & Moscow & 13532 & 20.8 \\
\hline Tyumen Region & 570 & 9.9 & Tyumen Region & 5850 & 9.0 \\
\hline Krasnoyarsk Territory & 215 & 3.7 & Moscow Region & 3213 & 4.9 \\
\hline St. Petersburg & 188 & 3.3 & St. Petersburg & 3023 & 4.7 \\
\hline Republic of Tatarstan & 186 & 3.2 & Krasnodar Territory & 1946 & $3 ., 0$ \\
\hline Sverdlovsk Region & 156 & 2.7 & Republic of Tatarstan & 1833 & 2.8 \\
\hline Republic of Bashkortostan & 145 & 2.5 & Sverdlovsk Region & 1779 & 2.7 \\
\hline Samara Region & 140 & 2.4 & Krasnoyarsk Territory & 1618 & 2.5 \\
\hline Krasnodar Territory & 137 & 2.4 & Republic of Bashkortostan & 1317 & 2.0 \\
\hline Perm Territory & 124 & 2.2 & Samara Region & 1241 & 1.9 \\
\hline 10 leading subjects & 3020 & 52.4 & 10 leading subjects & 35352 & 54.3 \\
\hline $\begin{array}{l}\text { GRP for subjects of the } \\
\text { Russian Federation }\end{array}$ & 5754 & 100 & $\begin{array}{l}\text { GRP for subjects of the } \\
\text { Russian Federation }\end{array}$ & 64997 & 100 \\
\hline
\end{tabular}

The difference in GRP between the first and the last regions exceeds 400 times, the gap in GRP per capita amounts to 54 times. The leading positions in the rating on the volume of GRP are traditionally occupied by the Moscow and Tyumen regions.

\section{Results and discussion}

Russian regions differ significantly in terms of standard and quality of living of the population. According to RIA Rating data on the level and distribution of wages in Russian 
regions, the average wage of the first (the Yamalo-Nenets Autonomous Area) and the last regions (the Republic of Dagestan) in 2017 differed in 4.3 times. In the integrated rating of regions (72 indicators), the leading positions in living standards are taken by Moscow, St. Petersburg, the Moscow Region, the Republic of Tatarstan, the Krasnodar Territory. The Republic of Tuva, the Republic of Ingushetia, the Republic of Kalmykia, the Republic of Altai, and the Jewish Autonomous Region close the rating.

The index of economic security which allows predicting inequality of economic development is the index of investments in fixed assets. In terms of investments in fixed assets, the first and the last regions differ almost in 190 times while the index of investments in fixed assets per capita of the region taken the first place in the rating is higher in 131 times than that of the last one (RIA Rating data). The multiple excess of investments in fixed assets in different regions leads to the conclusion on maintaining inequality of regional development in the future. Differences in the innovative activity of Russian regions, which is one of the factors of financial security, are also quite significant [3-6].

The 2016 investment attractiveness rating of Russian regions, compiled by the specialists of the National Rating Agency, also demonstrated the strengthening of regional imbalances. Almost all regions with upward trend were in the top half of the rating, downward trend regions were mostly at the bottom of the list. The best regions continue scaling up their investment attractiveness, while outsiders keep on losing ground. The most attractive regions for investments are Moscow and St. Petersburg, the Moscow region, the Leningrad region, the Tyumen region, the Tomsk region, the Sakhalin region, the Kaluga region, the Belgorod region, and the Republic of Tatarstan.

Debt load index is a significant indicator of the regional economic security. It is defined as the ratio of the state debt of the Russian Federation subjects to tax and non-tax revenues of the budget. At the end of 2016, the debt load index ranged from zero indicators (the Sevastopol and Sakhalin regions) to 176 percent (the republic of Mordovia), according to RIA Rating data. The level of debt load exceeding 100 percent was observed in eight Russian regions, 53 regions demonstrated the debt load exceeding 50 percent.

The challenging matter of regional development remains its differentiation. The issues of ensuring regional economic security are given attention in normative and legal documents aimed at ensuring national security as a system and its structural elements (economic security, ecological security, food security, energy security, etc.). In the Strategy of National Security of the Russian Federation (Presidential Decree of December 31, 2015, No. 683) regional economic security is defined as a component that can negatively affect national security under certain circumstances. The stable condition of national security at the regional level is ensured through the balanced, comprehensive, and systemic development of the components of the Russian Federation and the widening and strengthening of economic links among them (Article 64). The effectiveness of government programs of socioeconomic development of Russian regions is evaluated in the work of V. Leksin and B. Porfiriev [7].

The balanced spatial and regional development of the Russian Federation, strengthening the unity of its economic space is stated as one of the main directions of the government policy in the sphere of ensuring economic security (the Strategy of Economic Security of the Russian Federation until 2030, Article 15). The document sets the following main objectives: improving the territorial planning system in view of challenges and threats to national security; improving the national system of resettlement, creating conditions for the development of urban agglomerations; reducing the level of interregional differentiation in the socioeconomic development of the Russian Federation; expanding and strengthening economic links between the subjects of the Russian Federation; creating interregional production and infrastructure clusters; priority developing the economic potential of Eastern Siberia, the Far North, the Far East, the North Caucasus, the Crimea and the Kaliningrad 
region; developing the Northern Sea Route, modernizing the Baikal-Amur and TransSiberian Railways (Article 20).

To evaluate the level of economic security, it is very important to make managerial decisions. Assessment of national and regional economic security is carried out from various positions: analyzing economic security using risk-oriented models [8]; developing systems of monitoring and level assessment of economic security on the basis of indicators of sustainable development [9-10]; making the comprehensive assessment of the economic security and industrial safety of resource-producing regions [11-12]; estimating the effectiveness of regional economic security system [13], etc.

It should be noted that the Strategy of Economic Security of the Russian Federation until 2030 defines the indicators to be used for assessing the state of economic security. Some of the 40 indicators mentioned can be applied for regional economic security: the public debt of the Russian Federation subjects, the level of economic integration of the Russian Federation subjects, and the deficit of consolidated budget of the Russian Federation subjects (Article 27). Until 2019, it is planned to develop and implement a set of organizational, regulatory and methodological measures to ensure economic security, improve mechanisms for monitoring and assessing the state of economic security.

Of the indicators defined in the Strategy, the following indicators can be used at the regional level:

- the degree of depreciation of fixed assets;

- the index of industrial production;

- the index of labor productivity;

- the price index;

- the tension coefficient on labour market;

- the share of investments in machinery, equipment and vehicles in total fixed capital investments;

- the share of innovative goods, works, services in total volume of shipped goods, works, services;

- the share of organizations engaged in technological innovation;

- the proportion of the working-age population in the total population;

- the share of citizens with substandard incomes;

- the index of production by the type of economic activity "mining";

- the retail turnover;

- the distribution of people involved in economic activity by level of education;

- the decile coefficient (the income ratio of 10 percent of the most well-off population and 10 percent of the poorest population);

- the share of employees with wages below the subsistence level;

- the level of crime in the economy.

Subject to adaptation (the use of GRP instead of GDP), the following indicators can also be used: the index of physical volume of GRP; the GRP per capita; the share of GRP in GDP; the share of investment in fixed assets in GRP; the energy intensity of GRP; the share of high-technology and science-intensive products in GRP.

In our opinion, for industrial and mining regions, it is advisable to further define the share of the population living in single-industry towns; the share of industrial production in value terms that is produced in single-industry towns in the total industrial production of the region in value terms; the share of products exported in value terms; the share of loss-making enterprises; and involvement of regional enterprises in global added value chains.

For the analysis of economic security, it would be useful to set the threshold requirements of indicators specifying their minimum and maximum boundaries at the level of the country, region and municipalities. Perhaps, at the regional and municipal levels, the threshold 
requirements should differ for groups of regions and municipalities (for example, depending on specialization, the starting conditions for economic activities, etc.).

To develop the methodological apparatus for economic security analysis it is necessary to identify some criteria for scaling the state of economic security of the country / region, for instance, stable, pre-crisis, crisis, catastrophic, etc. It is also possible to create a model of integrated assessment of regional economic security with a certain proportion of security indicators.

\section{Conclusion}

Assessing the current state and the possibilities for the regions to move towards sustainable development, it is worth mentioning that today this theory is not yet a guide to action at different levels for all subjects of economic relations. The economic security of Russian regions is currently characterized by the insufficient level of economic security, which is manifested in significant differentiation of regional development. The matter can be settled by means of concerted actions of federal and regional authorities, the effective functioning of enterprises and the involvement of the population in the implementation of strategic directions of regional development, adequate to external and internal conditions of functioning.

\section{References}

1. I. Levitskaya, N. Pastukhova, O. Dubrovskaya, E3S Web of Conferences, 15, 04008 (2017)

2. S. Zhironkin, M. Gasanov, G. Barysheva, E. Gasanov, O. Zhironkina, G. Kayachev, E3S Web of Conferences, 21, 04002 (2017)

3. N. Kudrevatykh, T. Snegireva, A. Tselischeva, E3S Web of Conferences, 15, 04006 (2017)

4. S. Bereznev, O. Zonova, E. Lubkova, E3S Web of Conferences, 15, 04002 (2017)

5. E. Dotsenko, N. Ezdina, E3S Web of Conferences, 15, 04012 (2017)

6. V. A. Malakhov, T. G. Dubynina, Studies on Russian Economic Development, 27:4, 429 (2016)

7. V. N. Leksin, B. N. Porfiryev, Studies on Russian Economic Development, 27:4, 418 (2016)

8. E. Karanina, D. Loginov, IOP Conference Series: Earth and Environmental Science, 90, 012087 (2017)

9. N. A. Kazakova, A. I. Bolvachev, A. L. Gendon, G. F. Golubeva, Studies on Russian Economic Development, 27:6, 638 (2016)

10. S. V. Kazantsev, Regional Research of Russia, 2:1, 34 (2012)

11. E. B. Bukharova, S. A. Samusenko. A. R. Semenova, Regional Research of Russia, 7:3, 237 (2017)

12. S. Smagina, O. Kadnikova, K. Demidenko, G. Chistyakova, A. Rolgayzer, E3S Web of Conferences, 21, 04020 (2017)

13. Yu. Lysenko, Ja. Zelenskaya, SHS Web of Conferences, 35, 01043 (2017) 